\title{
A Brief History of MUNASA: McGill Non-Academic Staff Association
}

\section{by Gordon Burr}

\begin{abstract}
MUNASA is a voluntary organization created to represent all McGill University non-academic staff in 1972. After gaining recognition from the University it negotiated many major policies for McGill employees including Summer Friday vacations and greater rights for causal employees. When many McGill employees (clerical, library assistants and technical staff) decided to form a union, MUNASA reconstituted itself in 1995 as a voluntary organization for management staff. This paper began as a talk to commemorate the 40th Anniversary of MUNASA on June $12^{\text {th }} 2012$ at the meeting of CACPUQ held at the Macdonald Campus of McGill University.
\end{abstract}

\section{RESUMÉ}

Créé en 1972, MUNASA est une organisation bénévole, non affiliée et non syndiquée qui représente les gestionnaires, les techniciens et le personnel de bureau et les employés des bibliothèques de l'Université McGill. Après avoir acquis la reconnaissance de l'Université, MUNASA a réussi à négocier des politiques pour les employés et le personnel non enseignant incluant la politique d’obtention de congés les vendredis matin pendant l'été au lieu d'avoir une augmentation salariale ainsi que la nouvelle politique pour les droits du personnel temporaire. En 1995, la création du syndicat MUNACA a eu pour conséquence la perte des employés de bureau, des techniciens et des employés de la bibliothèque au sein de MUNASA. La seule catégorie d'employé restante était celle de la gestion. MUNASA a réussi à garder son rôle en s'affirmant lors des discussions avec l'Université sur les politiques concernant les gestionnaires. Ce document est un discours qui fut présenté le 12 juin 2012 lors de la réunion du CACPUQ au campus Macdonald de l'Université McGill pour la célébration du 40e anniversaire de MUNASA.

\section{Background}

$\mathrm{M}$ cGill University has a reputation in Quebec as being a bastion of Anglo- Saxon Protestant elitism. ${ }^{1}$ This idea, when coupled with the close association of the University since the $19^{\text {th }}$ century with such wealthy Anglo leaders of the Montreal business community as Lord Strathcona, William Macdonald, Edward Beatty and J.W. McConnell, reinforced the idea of the University as a private entity removed from public scrutiny. By the 1970's this conception of McGill was only a myth. The reality was very different. The Anglo business elite was in decline, language legislation was in place to promote the use of French in the workplace, the student revolt had led to the opening of University governance to not only students, but to academic staff and even non-academic staff. By 1978 Stanley Frost, the university historian could declare that McGill was a "secular, cosmopolitan university in the Canadian tradition" and with government funding McGill was no longer a private institution. ${ }^{3}$

\section{Quiet Revolution}

The Montreal anglophone community's isolationist attitude concerning the Francophone majority of Quebec society had been under review since the advent of the Quiet Revolution in the early 1960's. The rise of new state run bureaucratic structures and the attendant regulations made the more informal decision making structures of the anglophone community seem out of date and irrelevant. ${ }^{4}$ The inclusion of more groups in the societal power structures, growth of government funding along with unions and employee associations led to changes in the internal dynamic of Quebec universities including McGill.

These changes in Quebec society were absorbed only gradually and piecemeal into the McGill milieu. The creation of an association to represent employees is but one reflection of how these societal trends played out in the specific context of the workplace culture of McGill. In the McGill context the loyalty of employees to the University, the perceived need to collectively defend the rights of non-academic staff and an external push for unionization on the campus were the three 
most important influences on the creation of MUNASA (McGill University Non-Academic Staff Association). The establishment of a McGill oriented employee organization was also encouraged by the Vice-Principal responsible for the administrative services of the University, Stanley Frost. Frost felt that this alliance of non-academic staff was required to ensure balanced, effective negotiations by the University with all employee groups on salary and benefits. Otherwise faculty, through MAUT, and unionized staff, through their unions, would emerge with the bulk of salary and benefits. ${ }^{5}$

\section{Frustrations of McGill Employees}

By the early 1970's frustration was mounting amongst nonacademic staff over the lack of a meaningful dialogue with the senior administration. Many non-academics lamented the senior administration's paternalistic approach of frequently enacting policies without consultation from the very people (non-academic staff) who were expected to implement them. ${ }^{6}$

\section{Loyalty to McGill}

In a 1974 interview, McGill Principal Robert Bell was asked why non-academics came to work at McGill. Bell responded quite frankly that he felt one of the main reasons was a more fulfilling working environment then in industry. ${ }^{7}$ A noteworthy element in Bell's response is his acknowledgment of the unique work environment of a University where teaching and research were conducted to improve societal knowledge. This view shared by many McGill employees evoked a very strong sense of loyalty to the University.

Into this particular collegial environment lacking any structured voice for employee groups, the collective voice of MUNASA was born. A group of managers set out to create an association to represent the interests of all non-academic employees whether managers or clerical or technical staff. ${ }^{8}$ The goals were to achieve recognition as the official representative of its members and to better the conditions of the non-academic staff. ${ }^{9}$

\section{Birth of MUNASA}

MUNASA (McGill Non-Academic Staff Association) was founded at 6:10 P.M. on November 30, 1972. The nine founding members, mostly managers, were Jim McVety, Stu Budden, Ed DesRosiers, Louise Biernaski, Ray Bartschat, George Franks, Derek Remsen, Leo Kerklaan and J.P. Schuller. The interim executive was selected at this meeting with Stu Budden as Chair and Jim McVety as Secretary. Membership would be open to all non-academic staff that were either not represented by other staff associations or not included in collective agreements.

Six days later, on December 6 1972, the first general meeting was held with an attendance of two hundred and sixty employees. Stu Budden addressed this meeting and discussed some of the particularities of working at McGill University for the non-academic staff. He depicted the University as distinctly different from industry. The McGill environment, he mentioned, dedicated to the education of students engendered great devotion to the job and a strong sense of community. He contended that managers, technical and clerical staff could often be at cross purposes in their work roles but could unite on issues of fringe benefits and working conditions to the betterment of all concerned.

The conflicting workplace interests of technical, clerical and middle management staff could be reconciled, he argued, if the focus was on proceeding in a cautious, rationale manner where the common interests such as benefits were stressed and everyone's voice could be heard in the structured consultative process. Budden's mantra for MUNASA was "there are no bosses in the organization just members" ${ }^{10}$. He argued that there exists a mutual "interdependence" between students, academics, non-academics and administrators. Therefore, the non-academic employees should have an input into decisions of the university since they will be affected by any decisions made."11

The intention was to create a voluntary, unaffiliated, nonunion organization. The democratic nature of organization was also confirmed by Budden's promise that all of these other issues would be debated and ultimately determined by the majority of the membership under a constitution. ${ }^{12}$

\section{Governance}

The constitution and by-laws of MUNASA were approved at a SpecialGeneral Meeting on March 21,1973 with the election of officers occurring in April 1973. MUNASA consisted of councils representing different classifications of workers. The original councils were Technical, Clerical, Macdonald College (based on the distinct identity and location of this campus), and Management, with Library Assistants being added in 1975. The executive council consisted of President, Executive Vice-President, Vice President Liaison, Treasurer and Secretary as well as 7 representatives from the councils. ${ }^{13}$ The first president of MUNASA in 1973 was Stu Budden, a McGill accountant and a member of the M (Management) category.

Each council had independent authority to act for their particular members. This right was chiefly exercised in the area of grievances. The potential conflict of management and clerical employees was assuaged through this approach. In order to have a balance of interests on the executive and reflect the relative number of members within the councils the clerical and technical councils were entitled to two members each on the executive with the remaining three councils having a single member. The 5 officers were elected from all the members in order to ensure that no one council or group could control the organization. ${ }^{14}$ 


\section{Progress in employee policies and recognition by the University}

In 1974 MUNASA participated in various processes to improve the voice of non-academic staff of the University. Jim McVety reported in June 1974 that MUNASA would appoint members to an electoral college based on their membership numbers to vote on non-academic members to the Board of Governors and the Pensions committee. ${ }^{15}$

During that same year MUNASA struck a personnel policy review standing committee. This committee's goal was to investigate policies in the areas of salaries, job classifications, educational opportunity, seniority, promotion and job security. In the committee's December report MUNASA asked the University to provide free tuition for McGill employees taking McGill courses and stressed the necessity of providing free staff French language courses to all McGill staff citing the then recent language legislation. ${ }^{16}$ The staff French courses also provided an opportunity for members from different offices and job categories to meet in a work related yet informal setting. Typically they were 2 hours per week; most people used one hour of work time and one hour of their own time.

The second President of MUNASA, Ida Godefroy, in her President's report for 1974 proclaimed that in the second year of its existence the association had made significant contact with the administration on a variety of issues and in her words "we can say with confidence that major decisions which effect affect us will no longer, as they were in the past, be decided without our views being sought out and listened to attentively."17

\section{The Union debate of 1974-75}

The liveliest debate in 1974-75 centred on whether MUNASA should become a union. The decision recorded in the minutes of the Annual Meeting from January 28, 1975 was a resounding no. ${ }^{18}$ For Godefroy the advantages of an association included membership across all sectors of the university including managers and supervisors, lower costs to employees and the flexibility to open negotiations at any time on issues. The chief disadvantages were no legal strike status, no strike fund, and no signed contract. ${ }^{19}$

In 1975 the third president Dave Stephenson, a medical technician, gave as the rationale for MUNASA that it was "the only way that the administrative body of McGill can get a collective opinion from non-academics.20 $\mathrm{He}$ clearly preferred an association to a union citing reasons such as greater flexibility and less confrontational stances. ${ }^{21}$

\section{Policy Gains}

By 1976 MUNSA claimed the following policy gains on the part of its membership: better salaries including cost of living adjustments, education plan and on-campus health care $^{22}$ along with the establishment of a grievance procedure with an external arbitrator moving away from the older practice of having the Principal decide as the court of last resort. ${ }^{23}$

\section{Employment Security}

In 1976 MUNASA achieved an employment security policy based on three years of service with guarantees that the employee had a right to another position at the same level of salary and classification until a new position was found. ${ }^{24}$ President Stevenson viewed this agreement that drew upon the experience of a similar policy at the Université de Montreal as a major accomplishment of MUNASA. The rationale for this policy was that MUNASA members' preferred economic security over generous lay off packages. ${ }^{25}$

\section{Parity}

A parity agreement signed in 1976 on June $9^{\text {th }}$ with the University acknowledged the principle of "equal pay for equal work". This included all non-academic employees not covered by other agreements. The new scales for clerical and library staff based on scales at the Université de Montréal meant that most McGill employees would receive increased salaries. The University agreed to endeavour to adhere to the same principle for employees paid on research funds. ${ }^{26}$

By 1978 parity in the non-salary areas had been greatly enhanced through vacation entitlement becoming standardised at 4 weeks after 3 years of service and the introduction of two floating holidays. ${ }^{27} \mathrm{Jim}$ McVety, the chair of the MUNASA negotiating committee, reported that McGill had revised their vacation policies to bring them in line with similar policies at other Quebec Universities. ${ }^{28}$

\section{MUNASA in the Johnston era}

In February 1979, Allan Youster, president from 19781987, writing to Principal elect David Johnston spelled out the philosophy of the organization. It was a voluntary organization comprising 1300 members from a pool of 2100 . There was no legal status for the association and unlike most labour organizations in Quebec MUNASA sought a cooperative collegial relationship with the University and did not follow the adversarial approach of their colleagues at other institutions. "Our membership believes that that a functioning relationship built on this approach has to be healthier and more productive for both the University and the staff than the standard adversary approach commonly seen with unions" ${ }^{\prime 29}$ Johnston wrote back to support MUNASA stating that it "accords quite closely with my own view of government within the University".30

This type of approach is reflected later that year in the face of budget difficulties, Youster pledged to Vice Principal 
Finance John Armour that "MUNASA will be giving serious consideration to what it can do to help deal with the problem" to "bring about a renewed and strengthened spirit of cooperation between the various constituents of the University community." ${ }^{31}$ In a letter written to Principal Johnston, Youster offered to accept a $2.2 \%$ reduction in merit as long as MAUT (academic staff association) also limited the salary increases to the same level as MUNASA. ${ }^{32}$ In the same letter he sought to establish a sub-committee reporting to the Board of Governors to be responsible for the direction of salary and staff relations policies to match a similar committee for academic staff. ${ }^{33}$ This proposal led to the creation of the Non-Academic Salary Policy Committee in $1979 .{ }^{34}$

By 1976 McGill University through regulations that applied to all Quebec universities had reduced hours by giving Friday afternoons off in the summer between from June $24^{\text {th }}$ to the last work Friday before the Labour Day weekend. In 1981 responding to budget difficulties on the part of the University non-academic staff accepted in lieu of a merit increase to have Friday mornings off as well..$^{35}$

In 1985 the Task Force on Finances created by the Board of Governors to advise the Principal concerning the deficit included a member from MUNASA. ${ }^{36}$ The McGill offer to employees that they accept $2.5 \%$ less in pay increases was controversial. ${ }^{37}$ However, the MUNASA executive recommended acceptance of the agreement arguing that for most McGill non-academic employees "involvement with McGill is not simply a job but is part of their life and McGill is not an employer but rather a community to which they belong." In the President's Annual Report of 1985 the deficit caused by the underfunding of the University had made regular pay increases problematic but the hope was that out of this crisis could emerge a greater feeling of team spirit to help improve employee morale. ${ }^{39}$

In his last presidential report (1987) Youster cited the successes of MUNASA in achieving improvement in policies such as employment security, grievance procedures, staffing policy, parental leaves policy and Summer Fridays. He also noted that negotiations on a casual employment policy had entered its sixth year with little headway being made. ${ }^{40} \mathrm{He}$ lauded the role that MUNASA played in helping the "second class citizens (of McGill who) get lost in the shuffle".

\section{Formulation of a casual payroll policy and the creation of MUNACA}

In 1988 Irene Tenant became the second woman president of MUNASA but served only a few months. She cited the creation of an Employee Assistance program as the main accomplishment during her tenure and called the presidency "an enlightening experience."41 Irene was succeeded as president in a by election in September 1988 by Trevor Garland. Trevor joined MUNASA in 1975 when he came to McGill, served as an M (Management) council representative for 5 years, then as an executive officer (vicepresident Liaison) from 1985-1988. Trevor presided over his first executive committee meeting on October 3,1988 ${ }^{42}$ and served as president until 2007.

The first major policy implementation for the new president was on casual policy. In 1989 the University agreed to the regularization of casual positions at McGill. MUNASA estimated that this could create 100 new regular positions. ${ }^{43}$ Casual employees received far fewer benefits than regular employees, often performing the same tasks as regular employees and sometimes holding the position for many years. ${ }^{44}$ They were not entitled to job security and were ineligible for pensions or the same vacation policy as full time McGill employees.

Under the new policy, casual employees who had worked at the same job for three years were eligible to have their position converted into a full time permanent one with the same rights as other non-academic employees. Regular employees who had been casual employees were eligible to have their period of casual employment added to the years of service for benefits such as vacation entitlement. The casual policy also limited the employment of casuals to leave

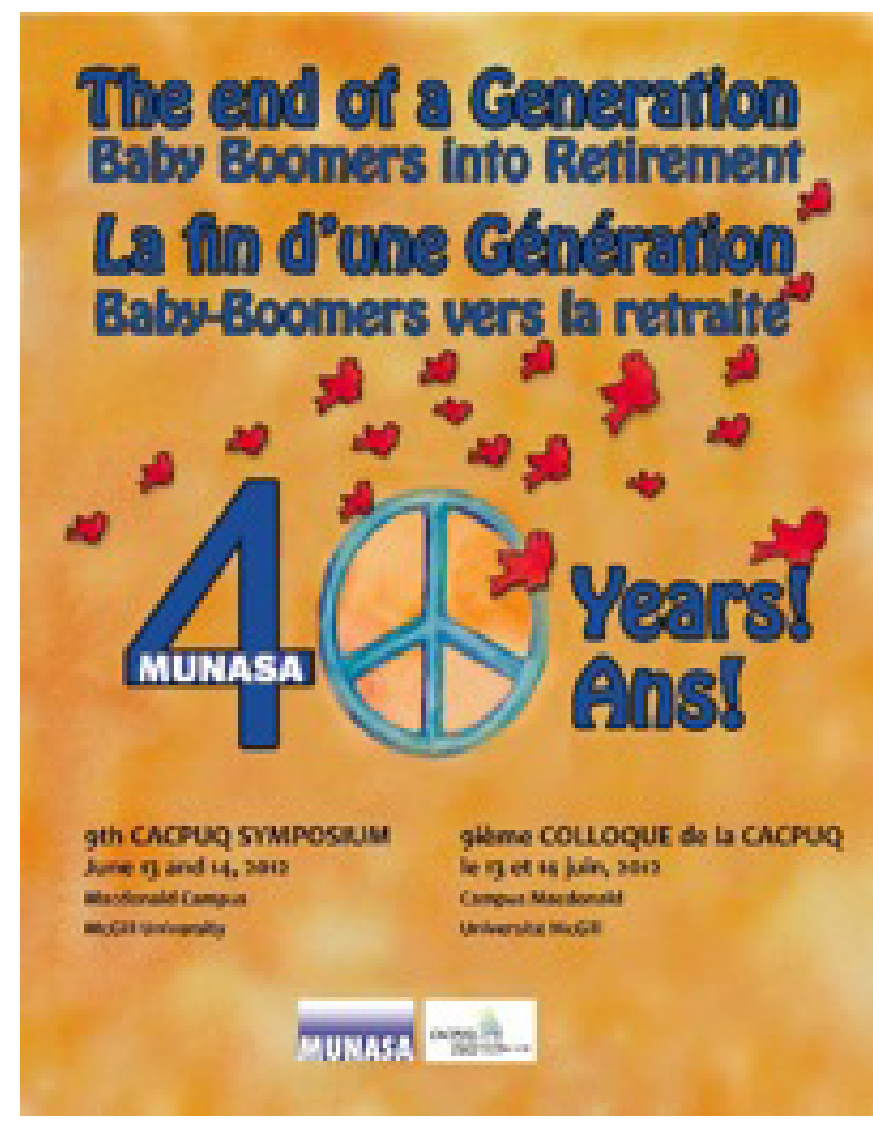

Celebration of the 40th Anniversary of MUNASA at the CACPUQ Conference on The End of a Generation : Baby Boomers into Retirement June 2012. From the website of MUNASA accessed June 29th, 2013 http://www.munasa.com/CACPUQ.html 
replacement, temporary replacements up to a maximum of 26 weeks, and excluded fulltime McGill students from the exigencies of this policy. ${ }^{45}$

The policy sparked controversy from the academic sector of the University due to the impact it might have over the employment of personnel in academic departments and in particular for those employees paid on research funds. Trevor Garland lamented “Don't academics have any respect for non-academics and the role we play in making McGill one of the best universities in the world?" ${ }^{46}$

\section{Changes in relations with the University}

By the early 1990's in an era of ongoing budgetary problems the role of MUNASA had evolved with an increasing focus as a representative of employee interests. This change is reflected in this quote from Trevor Garland in 1992 :

The simplest and most accurate description of our relations with the Administration is one word... Adversarial. ...That sounds bad, but actually it is good because it is clear. Our job in M.U.N.A.S.A. is labour relations, representing employees. In labour relations, the Administration represents the employer. Two very different things, quite opposite each other in fact. The employer concerns himself with what is best for the employer. The employee concerns himself with what is best for the employee. Reaching an agreement that bridges those opposing interests hopefully provides what is best for both.

\section{Post 1995-MUNASA survives}

By 1995 under pressure from years of budget cuts, nonmanagement staff at McGill turned to a union model to protect their collective rights. The creation of the MUNACA union in 1995 meant the loss of technicians, clerical staff and library assistants from MUNASA. The only remaining category was the $\mathrm{M}$ or management section. In 1995 the University ceased to recognize MUNASA as an entity and McGill sought to establish a new set of relationships with the managerial staff. Under challenge from the University ${ }^{47}$ MUNASA survived by legally reconstituting itself in 1995. It then participated in discussions over the following years with the University on a number of issues including the implementation of an $M$ Compensation system, performance planning, a merit based system and the creation of performance dialogue. MUNASA continues to defend the rights of its members through a revamped grievance process. ${ }^{48}$ The association has also participated in joint projects with the McGill Association of University Teachers on university governance and McGill unions including MUNACA on the issue of staff benefits.

\section{Conclusion}

The informal workplace style of McGill praised by Principal Bell in the 1970's, like that of most Universities, has been replaced in recent times by a more structured bureaucratic approach much closer to corporate or business models. The challenge for MUNASA under current president Ron Critchley remains, however, the same as the one originally pursued in 1972, finding ways to promote equity within the workplace.

\section{Appendix I-Presidents of MUNASA}

\begin{tabular}{l|l}
1973 & Stu Budden \\
1974 & Ida Godfrey \\
$1975-1978$ & David Stevenson \\
$1978-1988$ & Alan Youster \\
1988 & Irene Tennant \\
$1988-2007$ & Trevor Garland \\
2008 & Ronald Critchley
\end{tabular}

\section{ENDNOTES}

This is based on a talk given at $9^{\text {th }}$ CACPUQ Symposium, June $13^{\text {th }}, 2012$. Copies of some newsletters and other publications are in the McGill University Archives; most original records are held by MUNASA.

${ }^{1}$ Stanley Brice Frost. The History of McGill in Relation to Montreal and Quebec. La commission d'études sur les universités, 1978. p.9.

${ }^{2}$ Ronald Rudin. The forgotten Quebecers: A History of English Speaking Quebec, 1759-1980. p.213.

${ }^{3}$ Frost, Ibid.

${ }^{4}$ Sheila McLeod Arnopoulos and Dominque Clift, The English Fact in Quebec. Second Edition. 1984., p.104.

${ }^{5}$ Telephone interview with historian of McGill University, Peter McNally, May 17, 2012.

${ }^{6}$ MUNASAN Volume 5, Number 1, January/February 1977.

${ }^{7}$ MUNASAN Volume 2, Number 4, June 1974.

${ }^{8}$ MUNASAN Volume 5, Number 1, January/February 1977.

${ }^{9}$ MUNASA, Minutes, November 30, 1972.

${ }^{10}$ MUNASAN Volume 5 Number 7, November, December 1977.

${ }^{11}$ MUNASAN Volume 1, Number 1, May 1973.

${ }^{12}$ MUNASA, Minutes of First General Meeting, December 6, 1972.

${ }^{13}$ MUNASAN Volume 5, Number 7, November/December 1977.

${ }^{14}$ MUNASAN Volume 5, Number 7, November/December 1977.

${ }^{15}$ MUNASAN Volume 2, Number 4, June 1974.

${ }^{16}$ MUNASAN Volume 2, Number 8,November-December 1974.

${ }^{17}$ MUNASAN February, 1975 p.3.

${ }^{18}$ MUNASAN February, 1975 p.11.

${ }^{19}$ MUNASAN February, 1975 p.27.

${ }^{20}$ MUNASAN Volume 5, Number 4, January/February 1977.

${ }^{21}$ MUNASAN Volume 10, No.6, 1983 cites MUNASAN article reprinted from Volume 3, Number 1, 1975.

${ }^{22}$ MUNASA Brochure circulated April 1976.

${ }^{23}$ MUNASAN Volume 5, Number 1, January/February 1977. 
${ }^{24}$ MUNASAN Volume 4, Number 2, March 1976 p.13-14.

${ }^{25}$ MUNASAN Volume 6,Number 1 (Jan/Feb) 1978.

${ }^{26}$ Munasan extra issue, June 21, 1976.

${ }^{27}$ MUNASAN Volume 6,Number 1 (Jan/Feb) 1978.

${ }^{28}$ MUNASAN Volume 6, Number 3, April 1978.

${ }^{29}$ Letter Allan Youster to David L. Johnston, February 20, 1979. Outgoing executive correspondence Box 1 Comm1.1.

${ }^{30}$ Letter David L. Johnston to Allan Youster, February 26, 1979. Incoming executive correspondence Box 1 Comm1.1.

${ }^{31}$ Letter Allan Youster to John Armour, October 3, 1979. Outgoing executive correspondence Box 1 Comm1.1.

${ }^{32}$ Letter Allan Youster to David Johnston, October 15, 1979. Outgoing executive correspondence Box 1 Comm1.1.

${ }^{33}$ Letter Allan Youster to David Johnston, October 15, 1979. Outgoing executive correspondence Box 1 Comm1.1.

${ }^{34}$ Letter David L. Johnston to Letter Allan Youster, December 18, 1979. Incoming executive correspondence Box 1 Comm1.1.
${ }^{35}$ MUNASAN Volume 17, Number 7, October 1989.

${ }^{36}$ Letter David L. Johnston to Letter Allan Youster, January 23, 1985. Incoming executive correspondence Box 1 Comm1.1.

${ }^{37}$ Letter Allan Youster to David Johnston, November 27, 1981. Outgoing executive correspondence Box 1 Comm1.1.

${ }^{38}$ Letter David L. Johnston to Letter Allan Youster, November 19, 1981. Incoming executive correspondence Box 1 Comm1.1.

${ }^{39}$ MUNASAN, Volume13, no.1, March 1985.

${ }^{40}$ MUNASAN, Volume 16, Number 1, 1988.

${ }^{41}$ MUNASAN Volume 16, October 1988.

${ }^{42}$ MUNASAN, Volume 17, number 1, January 1989.

${ }^{43}$ MUNASAN Volume 17, number 7, October 1989.

${ }^{44}$ MUNASAN Volume 17, number 7, October 1989.

${ }^{45}$ MUNASAN Volume 17, Number 5, June 1989.

${ }^{46}$ MUNASAN Volume 17, Number 7, October 1989.

${ }^{47}$ Annual General Meeting_President's report-Jan. 25, 2008.

${ }^{48} \mathrm{Ibid}$. 